\title{
Iwona Miedzińska
}

\section{Prawa czlowieka w polityce zagranicznej Unii Europejskiej - aspekty prawne}

Przedmiotem artykułu są zagadnienia prawne związane z prawami człowieka w unijnej polityce zagranicznej. Unia Europejska („UE”) promuje poszanowanie praw człowieka nie tylko w państwach członkowskich, ale również w swoich działaniach zewnętrznych stosunkach $\quad \mathrm{z}$ państwami trzecimi i organizacjami międzynarodowymi. Zgodnie z art. 21 Traktatu o Unii Europejskiej, działania UE na arenie międzynarodowej oparte są na zasadach: demokracji, państwa prawnego, powszechności i niepodzielności praw człowieka i podstawowych wolności, poszanowania godności ludzkiej, zasad równości i solidarności oraz poszanowania zasad Karty Narodów Zjednoczonych i prawa międzynarodowego. Do głównych instrumentów realizacji celów UE w dziedzinie praw człowieka należy zaliczyć: przyjmowanie wytycznych polityki UE w zakresie kluczowych problemów dotyczących praw człowieka, włączanie problematyki praw człowieka i demokratyzacji do wszystkich aspektów związanych z podejmowaniem przez UE decyzji politycznych i ich wdrażaniem, w tym do pomocy zewnętrznej, włączanie klauzuli dotyczącej praw człowieka i demokracji do umów zewnętrznych zawieranych przez UE oraz europejski instrument na rzecz demokracji i praw człowieka.

\section{Wstęp}

Przedmiotem artykułu są zagadnienia prawne związane z prawami człowieka w polityce zagranicznej Unii Europejskiej (dalej: „UE”, „Unia”). Autorka stawia tezę, że prawa człowieka są istotnym aspektem polityki zagranicznej Unii, ponieważ organizacja ta promuje poszanowanie praw człowieka nie tylko w państwach członkowskich, ale również w swoich działaniach zewnętrznych. Celem badań jest próba znalezienia odpowiedzi na następujące pytania badawcze: czy prawa człowieka uwzględniane są w aktach prawnych dotyczących polityki zagranicznej Unii?; jakie są instrumenty realizacji celów unijnych w dziedzinie praw człowieka?; czy, a jeśli tak, to w jaki sposób, UE wykorzystuje instrumenty polityki zagranicznej do promowania ochrony praw człowieka? 
W pierwszej części artykułu autorka charakteryzuje genezę i etapy rozwoju ochrony praw człowieka w Unii. Następnie omówione zostaną ramy prawne UE w zakresie polityki zagranicznej, z uwzględnieniem aspektów odwołujących się do ochrony praw człowieka. Natomiast druga część pracy poświęcona jest instrumentom realizacji celów unijnych w dziedzinie praw człowieka, z uwzględnieniem działań podejmowanych przez UE w tym zakresie. Podstawową metodą badawczą zastosowaną w pracy jest metoda dogmatyczna, a badanymi źródłami - prawo pierwotne i prawo pochodne UE.

\section{Geneza i rozwój ochrony praw czlowieka w Unii Europejskiej}

Problematyka praw człowieka i ich ochrony jest bardzo istotna w działaniach Unii, zarówno w jej stosunkach wewnętrznych, jak i zewnętrznych. W tym miejscu należy zauważyć, że w dyskursie naukowym stosowana jest zróżnicowana terminologia, również w źródłach prawa unijnego terminy „prawa człowieka” i „prawa podstawowe” występują zamiennie ${ }^{1}$. Z kolei w odniesieniu do stosunków zewnętrznych UE najczęściej stosowane jest pojęcie „prawa człowieka”2. Na potrzeby niniejszego opracowania należy przyjąć, że pojęcia „prawa człowieka" ${ }^{3}$ i ,prawa podstawowe” są tożsame treściowo ${ }^{4}$.

Początkowo prawa człowieka nie były uregulowane w traktatach założycielskich Wspólnot Europejskich, których głównym celem była odbudowa i integracja gospodarcza Europy po II wojnie światowej ${ }^{5}$. Za pierwszy etap ich rozwoju należy uznać lata 60-te i 70-te XX w., kiedy Europejski Trybunał Sprawiedliwości (obecnie Trybunał Sprawiedliwości UE, dalej: „TSUE”) formułował koncepcję praw podstawowych, którą rozwijał w późniejszych orzeczeniach, a także włączył zasadę poszanowania praw podstawowych do katalogu ogólnych

${ }^{1}$ D. Bigos, Trybunat Sprawiedliwości Unii Europejskiej jako organ sprawujący kontrole sądowa nad przestrzeganiem praw czlowieka wymienionych w Karcie Praw Podstawowych [w:] Europejski system ochrony praw czlowieka. Aksjologia - instytucje - efektywność, red. J. Jaskiernia, Torun 2015, s. 96.

${ }^{2}$ B. Banaszak, A. Bisztyga, K. Complak, M. Jabłoński, R. Wieruszewski, K. Wójtowicz, System ochrony praw czlowieka, Kraków 2005, s. 199 i n.

${ }^{3}$ Na temat wieloznaczności tego pojęcia zob. K. Cymerys, Tendencje w zakresie ochrony praw czlowieka w świetle orzecznictwa Europejskiego Trybunatu Praw Człowieka [w:] Europejski system ochrony praw człowieka. Aksjologia - instytucje - efektywność, red. J. Jaskiernia, Toruń 2015, s. 11-13.

${ }_{4}$ Należy podkreślić, że na poziomie prawa UE brak jest definicji praw podstawowych - nie znajdziemy jej ani w dokumentach prawnych UE, ani w orzecznictwie Trybunału Sprawiedliwości. Inspiracją dla unijnego rozumienia tego pojęcia są tradycje konstytucyjne wspólne dla państw członkowskich.

5 Sferę praw i wolności człowieka uważano wówczas za dziedzinę aktywności Rady Europy oraz Organizacji Narodów Zjednoczonych (dalej: „ONZ”). Zob.: I. Miedzińska, Unia Europejska jako strona Europejskiej Konwencji Praw Czlowieka i Podstawowych Wolności - problemy prawno-instytucjonalne [w:] Nowe spojrzenia w naukach o polityce. Tom 2., red. W. Jakubowski, A. Krawczyk, J. Szczepański, Warszawa 2012; s. 71-72, I. Malinowska, Prawa człowieka w Unii Europejskiej, Warszawa 2005, s. 33-34; K. Marciniak, Ochrona praw podstawowych w stosunkach zewnętrznych Unii Europejskiej, [w:] Prawa podstawowe w prawie i praktyce Unii Europejskiej, red. C. Mik, K. Gałka, Torun 2009, s. 522-523. 
zasad prawa wspólnotowego ${ }^{6}$. Nigdy jednak instytucje wspólnotowe nie formułowały katalogu praw człowieka ani nie określały procedur ich ochrony i egzekwowania.

Zasadnicza zmiana nastąpiła w wyniku wejścia w życie tzw. Traktatu z Maastricht (oficjalnie: Traktat o Unii Europejskiej, dalej: „TUE”)", który ustanowił m.in. pojęcie obywatela UE, przyznając mu uprawnienia takie jak: swoboda poruszania się i pobytu na terytoriach państw członkowskich UE, czynne i bierne prawo wyborcze do Parlamentu Europejskiego i w wyborach lokalnych w państwie członkowskim miejsca zamieszkania, a także prawo składania petycji do Parlamentu Europejskiego i skarg do Ombudsmana UE ${ }^{8}$. Stąd też drugim etapem rozwoju praw podstawowych było wpisanie ich do aktów normatywnych, w tym proklamowanie Karty Praw Podstawowych Unii Europejskiej ${ }^{9}$ (dalej: „KPP”) 7.12.2000 r. Po raz pierwszy prawa podstawowe zostały wpisane do prawa pierwotnego UE w preambule do Jednolitego Aktu Europejskiego ${ }^{10}$, zgodnie z którą jednym z celów współpracy sygnatariuszy była promocja demokracji opartej o prawa podstawowe wywodzące się z konstytucji i prawa państw członkowskich oraz z Konwencji o ochronie praw Człowieka i podstawowych wolności (dalej: „EKPCZ”) i Europejskiej Karty Socjalnej. Kolejnym krokiem było podpisanie w Maastricht TUE, który w art. 6 ust. 2 w sposób wyraźny wprowadził prawa podstawowe do prawa pierwotnego UE, powtarzając w zasadzie orzecznictwo TSUE. Na mocy tego traktatu została ustanowiona Wspólna Polityka Zagraniczna i Bezpieczeństwa Unii Europejskiej (dalej: „WPZiB”), do której celów zaliczono m.in. rozwijanie i umacnianie demokracji i państwa prawnego, ochronę wspólnych wartości'i1 oraz poszanowanie praw człowieka i podstawowych wolności ${ }^{12}$. Tym samym omawiana problematyka bezpośrednio została powiązana ze stosunkami zewnętrznymi UE.

\footnotetext{
6 Zob. M. Sakslin, Charter of fundmental rights of the European Union and the Convention for the Protection of Human Rights and Fundamental Freedoms [w:] Obywatel w Radzie Europy i Unii Europejskiej, Warszawa 2014, s. 261-262; A. Florczak, Ewolucja ochronypraw człowieka w systemie prawa wspólnotowego [w:] Ochrona praw podstawowych w Unii Europejskiej. Wybrane zagadnienia, red. A. Florczak, Warszawa 2009, s. 11-15. Na temat podstawowych orzeczeń TS w przedmiotowej materii zob.: A. Andreangeli, EU Competition Enforcement and Human Rights, Massachusetts 2008, s. 6-10; K. Marciniak, op.cit., s. 523-527.

${ }^{7}$ Traktat o Unii Europejskiej (wersja skonsolidowana, Dz.Urz.UE 2012 Nr C 326/13).

${ }^{8} \mathrm{Na}$ temat praktycznych aspektów realizacji tych praw zob. Ochrona praw obywatelek $i$ obywateli Unii Europejskiej 20 lat - osiagnięcia i wyzwania na przyszłość, red. G. Baranowska, A. Bodnar, A. GliszczyńskaGrabias.

9 Tekst KPP w języku polskim zob. Dz.Urz.UE 2007 Nr C 303/1.

${ }^{10}$ Dz.Urz.UE 1987 Nr L 169/1.

${ }^{11} \mathrm{Na}$ temat roli wartości w porządku prawnym UE zob. Ł.J. Pikuła, Od zasad do wartości. Nowa jakość normatywna w porzadku prawnym UE [w:] Europejski system ochrony praw człowieka, op.cit., s. 75-83.

${ }^{12}$ Por. K. Marciniak, op.cit., s. 530.
} 
Trzeci etap rozwoju praw podstawowych to zmiany wprowadzone Traktatem z Lizbony ${ }^{13}$ (dalej: „TzL”), które de facto zostały wymuszone przez praktykę instytucji unijnych. TzL przede wszystkim nadał KPP moc prawną równą traktatom i umożliwił Unii przystąpienie do EKPCz ${ }^{14}$. Akcesja UE do EKPCz według autorki będzie czwartym etapem rozwoju praw podstawowych w systemie unijnym. Stosownie do treści art. 6 TUE przystąpienie do EKPCz nie będzie miało wpływu na kompetencje UE określone w Traktatach. Zgodnie z ust. 3 tego artykułu ,prawa podstawowe, zagwarantowane w europejskiej Konwencji o ochronie praw człowieka i podstawowych wolności oraz wynikające z tradycji konstytucyjnych wspólnych Państwom Członkowskim, stanowią część prawa Unii jako zasady ogólne prawa"15. W opinii 2/13 wydanej 18.12.2014 r. TSUE uznał, że projekt porozumienia dotyczącego przystąpienia UE do EKPCZ jest niezgodny z art. 6 ust. 2 TUE i z protokołem nr $8^{16}$, w związku z czym, stosownie do treści art. 218 ust. 11 Traktatu o funkcjonowaniu Unii Europejskiej (dalej: „TfUE”) ${ }^{17}$, nie może ono wejść w życie, chyba że nastąpi jego zmiana lub rewizja Traktatów.

\section{Ramy prawne Unii Europejskiej}

Zgodnie z art. 2 TUE Unia opiera się na następujących wartościach: poszanowanie godności osoby ludzkiej, wolność, demokracja, równość, państwo prawne, jak również poszanowanie praw człowieka, w tym praw osób należących do mniejszości. Wartości te są wspólne państwom członkowskim w społeczeństwie opartym na pluralizmie, niedyskryminacji, tolerancji, sprawiedliwości, solidarności oraz równości kobiet i mężczyzn. UE promuje poszanowanie praw człowieka nie tylko w państwach członkowskich, ale również w swoich działaniach zewnętrznych - stosunkach z państwami trzecimi i organizacjami międzynarodowymi.

Według art. 3 ust. 5 TUE w stosunkach zewnętrznych UE „umacnia i propaguje swoje wartości i interesy oraz wnosi wkład w ochronę swoich obywateli”18. Przyczynia się m.in. do pokoju, bezpieczeństwa, solidarności i wzajemnego szacunku między narodami, do swobodnego i uczciwego handlu, wyeliminowania ubóstwa oraz do ochrony praw

\footnotetext{
13 Traktat z Lizbony zmieniający Traktat o Unii Europejskiej i Traktat ustanawiający Wspólnotę Europejską sporządzony w Lizbonie 13.12.2007 r., Dz.U. z 2009 r. Nr 203, poz. 1569.

${ }^{14} \mathrm{Na}$ temat przystąpienia UE do EKPCZ zob. np.: I. Miedzińska, op.cit., s. 75-83.

15 Artykuł 6 ust. 3 TUE.

${ }^{16} \mathrm{http}: /$ curia.europa.eu/juris/document/document.jsf?docid=160882\&doclang=PL, dostęp: 30.7.2017.

${ }^{17}$ Traktat o funkcjonowaniu Unii Europejskiej (wersja skonsolidowana, Dz.Urz.UE $2012 \mathrm{Nr}$ C 326/47).

18 Artykuł 3 ust. 5 TUE.
} 
człowieka, w szczególności praw dziecka, a także do ścisłego przestrzegania i rozwoju prawa międzynarodowego, w szczególności zasad Karty Narodów Zjednoczonych.

Zgodnie z art. 21 TUE działania UE na arenie międzynarodowej oparte są na zasadach, które leżą u podstaw jej utworzenia, rozwoju i rozszerzenia, a które zamierza ona wspierać na świecie: demokracji, państwa prawnego, powszechności i niepodzielności praw człowieka i podstawowych wolności, poszanowania godności ludzkiej, zasad równości i solidarności oraz poszanowania zasad Karty Narodów Zjednoczonych i prawa międzynarodowego. Unia dąży do rozwijania stosunków i budowy partnerstwa $\mathrm{z}$ państwami trzecimi oraz z organizacjami międzynarodowymi, regionalnymi lub światowymi, które wyznają te zasady. Z ust. 2 cytowanego artykułu wynika, że UE określa i prowadzi wspólne polityki i działania oraz dąży do zapewnienia wysokiego stopnia współpracy we wszelkich dziedzinach stosunków międzynarodowych, w celu m.in. „umacniania i wspierania demokracji, państwa prawnego, praw człowieka i zasad prawa międzynarodowego"19. Ponadto, art. 205 TfUE stanowi, że działania UE na arenie międzynarodowej są oparte na zasadach określonych w art. $21 \mathrm{TUE}^{20}$.

Podstawowe znaczenie w zakresie zasad, celów i priorytetów Unii w obszarze praw człowieka mają Strategiczne ramy Unii Europejskiej dotyczące praw człowieka i demokracji ${ }^{21}$. Dokument ten został przyjęty przez Radę UE 25.6.2012 r. i ustala na 10 lat priorytety polityki UE w zakresie praw człowieka ${ }^{22}$, wśród których można wyróżnić m.in. następujące:

- promowanie wolności wypowiedzi i wyrażania opinii oraz wolności zgromadzeń i zakładania stowarzyszeń,

- działanie na rzecz praw człowieka w instytucjach wielostronnych oraz na rzecz zwalczania wszelkich przejawów dyskryminacji, w szczególności wobec kobiet,

- działanie na rzecz całkowitego zniesienia kary śmierci oraz tortur, jako poważnych naruszeń praw człowieka i ludzkiej godności,

- promowanie prawa do bezstronnego i sprawiedliwego procesu oraz równości wobec prawa,

- zintensyfikowanie politycznego i finansowego wsparcia obrońców praw człowieka,

\footnotetext{
${ }^{19}$ Artykuł 21 ust. 2 TUE.

${ }^{20} \mathrm{Na}$ temat zasad polityki zagranicznej Unii zob. H. Sjursen, Principles in European Union Foreign Policy [w:] International Relations and the European Union, edited by C. Hill, M. Smith, S. Vanhoonacker, third edition, Oxford 2017, s. 443-462.

${ }^{21}$ Prawa człowieka i demokracja: Strategiczne ramy UE i plan działania UE, http://data.consilium.europa.eu/doc/ document/ST-11855-2012-INIT/pl/pdf, dostęp: 30.7.2017 r.

${ }^{22}$ Załącznik II. Strategiczne ramy UE dotyczące praw człowieka i demokracji, http://data.consilium.europa.eu/ doc/document/ST-11855-2012-INIT/pl/pdf, dostęp: 30.7.2017 r.
} 
- zacieśnienie współpracy z Radą Europy oraz Organizacją Bezpieczeństwa i Współpracy w Europie.

Ramy stanowią podstawę do opracowywania i wdrażania poszczególnych działań zarówno dla instytucji unijnych, jak i poszczególnych państw członkowskich UE. Ich dopełnieniem stał się Plan działania UE dotyczący praw człowieka i demokracji (Załącznik III ważny był do 31.12.2014 r.). Obecnie obowiązuje plan działania na lata 2015-201923.

Odpowiedzialność za realizację poszczególnych zadań ujętych w Planie ponosi Wysoki Przedstawiciel Unii Europejskiej do Spraw Zagranicznych i Polityki Bezpieczeństwa, przy wsparciu Europejskiej Służby Działań Zewnętrznych (EEAS), Komisji, Rady, a także państw członkowskich. Do prawidłowej realizacji Planu przyczynia się także Specjalny Przedstawiciel Unii Europejskiej ds. Praw Człowieka - instytucja powołana decyzją Rady z 25.7.2012 r. ${ }^{24}$. Do jego obowiązków należy m.in. zwiększanie obecności i skuteczności UE w zakresie ochrony i propagowania praw człowieka, m.in. pogłębianie dialogu w dziedzinie współpracy politycznej Unii z państwami trzecimi, podmiotami gospodarczymi, społeczeństwem obywatelskim oraz organizacjami międzynarodowymi i regionalnymi, jak również poprawa spójności działań UE w zakresie praw człowieka i szersze uwzględnianie kwestii praw człowieka we wszystkich aspektach działań zewnętrznych Unii.

\section{Instrumenty realizacji na arenie międzynarodowej celów unijnych w zakresie praw czlowieka}

W praktyce polityka Unii w dziedzinie praw człowieka obejmuje różne instrumenty, których celem jest włączanie problematyki praw podstawowych we wszystkie strategie i programy, jak również finansowanie konkretnych projektów przy pomocy instrumentów finansowych UE, mających na celu promowanie i ochronę praw człowieka ${ }^{25}$. Należy jednak zauważyć, że WPZiB jest dziedziną współpracy o charakterze międzyrządowym,

\footnotetext{
${ }^{23}$ Konkluzje Rady w sprawie planu działania dotyczącego praw człowieka i demokracji na lata 2015-2019, http://data.consilium.europa.eu/doc/document/ST-10897-2015-INIT/pl/pdf, dostęp: 30.7.2017.

${ }^{24}$ Decyzja Rady 2012/440/WPZiB z 25.7.2012 r. w sprawie mianowania Specjalnego Przedstawiciela Unii Europejskiej ds. Praw Człowieka (Dz.Urz.UE 2012 Nr L 200/21) wygasła 28.2.2017 r. Obecnie obowiązuje w tym zakresie Decyzja Rady (WPZiB) 2017/346 z 27.2.2017 r. przedłużająca mandat Specjalnego Przedstawiciela Unii Europejskiej ds. Praw Człowieka (Dz.Urz.UE 2017 Nr L 50/66), która wygaśnie 28.2.2019 r.

${ }^{25}$ Wiele $\mathrm{z}$ nich uzasadnianych jest względami aksjologicznymi. Na temat aksjologicznych podstaw polityki zagranicznej UE zob. np. Z. Brodecki, Aksjologia polityki zagranicznej UE. Unia Europejska jako aktor globalny? [w:] Polityka zagraniczna Unii Europejskiej. Prawo i praktyka, red. J. Galster, A. Szczerba-Zawada, Warszawa 2016; Prawa czlowieka - aksjologia Unii Europejskiej, s. 15-16, http://orka.sejm.gov.pl/ WydBAS.nsf/0/A8F3C4315BAC2955C12578E30042928A/\$file/Prawa\%20cz\%C5\%82owieka.pdf, dostęp: 29.7.2017.
} 
dlatego podjęcie w jej obszarze większości działań na poziomie unijnym uzależnione jest de facto od woli politycznej państw członkowskich ${ }^{26}$.

\subsection{Rodzaje działań podejmowanych przez Unię w obszarze praw czlowieka}

Do głównych instrumentów realizacji wyżej wymienionych celów UE w dziedzinie praw człowieka należy zaliczyćc ${ }^{27}$ :

- przyjmowanie wytycznych polityki Unii w zakresie kluczowych problemów dotyczących praw człowieka,

- włączanie problematyki praw człowieka i demokratyzacji do wszystkich aspektów związanych z podejmowaniem przez UE decyzji politycznych i ich wdrażaniem, w tym do pomocy zewnętrznej,

- włączanie klauzuli dotyczącej praw człowieka i demokracji do umów zewnętrznych zawieranych przez UE,

- instrumenty finansowe i ogólny system preferencji,

- sankcje autonomiczne i sankcje implementowane przez UE.

Podstawowym narzędziem dotyczącym praw człowieka jest zawieranie umów międzynarodowych z państwami trzecimi na podstawie przepisów TfUE. Istotnym elementem tych umów jest klauzula praw człowieka, która pozwala na zawieszenie stosowania danej umowy w przypadku gdy prawa te są naruszane przez jedną z jej państw-stron. Niestety praktyka pokazuje, że stosowanie omawianej klauzuli nie jest jednolite - różni się w zależności od charakteru państw i regionu geograficznego, w którym dane państwo się znajduje, a w odniesieniu do niektórych państw, jak np. Chiny w ogóle jej nie wynegocjowano ${ }^{28}$. Niewątpliwie wyjątkową pozycję mają państwa Azji, Karaibów i Pacyfiku - klauzula w ich przypadku jest szczególnie rozbudowana i obliguje m.in. do podjęcia negocjacji przed zawieszeniem stosowania umowy ${ }^{29}$.

Instrumentem subsydiarnym w stosunku do umów UE z państwami trzecimi są różnego rodzaju środki autonomiczne przyjmowane przez Unię, wśród których należy wymienić instrumenty finansowe ${ }^{30}$ oraz ogólny system preferencji. Pierwsze wspomagają politykę UE

\footnotetext{
$26 \mathrm{Na}$ temat problemów związanych $\mathrm{z}$ kompetencjami UE w stosunkach zewnętrznych zob. np. A. Szmigielski, Prawa człowieka i demokracja w centrum działań zewnętrznych Unii Europejskiej. Dylematy prawne i polityczne, Przegląd Zachodni 2016, nr 1, s.12-15.

${ }^{27}$ Na podstawie: K. Marciniak, op.cit., s. 542 i n. oraz A. Szmigielski, op.cit., s. 12-16.

${ }^{28}$ K. Marciniak, op.cit., s. 587.

${ }^{29}$ Ibidem.

${ }^{30} \mathrm{Na}$ temat instrumentów finansowych UE dotyczących praw podstawowych zob. ibidem, s. 556-564.
} 
w zakresie praw człowieka poprzez umożliwienie dodatkowego finansowania zróżnicowanych projektów ich dotyczących. Najważniejszym z nich jest europejski instrument na rzecz demokracji i praw człowieka utworzony rozporządzeniem Parlamentu Europejskiego i Rady nr 1889/2006 z 20.12.2006 r. ${ }^{31}$, które wygasło z dniem 31.12.2013 r. Aktem prawnym obecnie obowiązującym $\mathrm{w}$ tym zakresie jest rozporządzenie $\mathrm{nr}$ 235/2014 z 11.3.2014 r. ${ }^{32}$, które wygaśnie 31.12.2020 r. Pomoc dostarczona w ramach tego instrumentu ma na celu m.in.: wzmocnienie poszanowania praw człowieka i podstawowych wolności w krajach i regionach, w których zasady te są najbardziej zagrożone; wspieranie społeczeństwa obywatelskiego w roli promotora praw człowieka i demokracji; wzmocnienie międzynarodowych i regionalnych ram ochrony praw człowieka oraz sprawiedliwości, państwa prawa i promowania demokracji, a także budowanie zaufania do demokratycznego procesu wyborczego poprzez wzmacnianie jego wiarygodności i przejrzystości, w szczególności poprzez misje monitorowania wyborów. Z kolei ogólny system preferencji ${ }^{33}$ pozwala na bardziej korzystne oclenie produktów pochodzących $\mathrm{z}$ państw rozwijających się, jeśli respektują one standardy praw człowieka, wyrażone $\mathrm{w}$ określonych umowach międzynarodowych.

Wśród instrumentów podejmowanych przez UE należy też wskazać na sankcje autonomiczne lub implementowane przez UE. Impuls do nałożenia tych pierwszych stanowi decyzja podejmowana na podstawie art. 29 TUE, zgodnie z którym „Rada przyjmuje decyzje, które określają podejście Unii do danego problemu o charakterze geograficznym lub przedmiotowym. Państwa Członkowskie zapewniają zgodność swych polityk krajowych ze stanowiskami Unii" ${ }^{34}$. Konkretne środki zmierzające do realizacji tej decyzji podejmowane są na podstawie TfUE. Zgodnie z art. 215 TfUE jeżeli decyzja, przyjęta zgodnie z tytułem $\mathrm{V}$ rozdział 2 TUE (postanowienia szczególne dotyczące WPZiB) przewiduje zerwanie lub ograniczenie $\mathrm{w}$ całości lub w części stosunków gospodarczych i finansowych $\mathrm{z}$ jednym lub z większą liczbą państw trzecich, Rada przyjmuje niezbędne środki, stanowiąc większością kwalifikowaną na wspólny wniosek wysokiego przedstawiciela Unii do spraw zagranicznych i polityki bezpieczeństwa oraz Komisji, informując o tym Parlament Europejski.

\footnotetext{
${ }^{31}$ Rozporządzenie WE nr 1889/2006 Parlamentu Europejskiego i Rady z 20.12.2006 r.w sprawie ustanowienia instrumentu finansowego na rzecz wspierania demokracji i praw człowieka na świecie (Dz.Urz.UE $2006 \mathrm{Nr}$ L 368/1).

${ }^{32}$ Rozporządzenie Parlamentu Europejskiego i Rady (UE) nr 235/2014 z 11.3.2014 r. ustanawiające instrument finansowy na rzecz wspierania demokracji i praw człowieka na świecie (Dz.Urz.UE 2014 Nr L 77/85).

${ }^{33}$ Instrument ten wiąże się ze Wspólną Polityką Handlową UE. Na temat jego wykorzystania w praktyce zob. K. Marciniak, op.cit., s. 565-568.

${ }^{34}$ Art. 29 TUE.
} 
Rada może też przyjąć takie środki wobec osób fizycznych lub prawnych, grup lub podmiotów innych niż państwa. Sankcje autonomiczne - czy też „środki ograniczające”, gdyż UE preferuje taką terminologię - mogą stanowić środek proaktywny, wymuszający przyjęcie pewnych standardów. Odróżnia się je od sankcji nakładanych przez Radę Bezpieczeństwa ONZ i implementowanych przez UE, jako że są one raczej reakcją na zaistniałe już naruszenie międzynarodowego pokoju i bezpieczeństwa.

\subsection{Realizacja celów w dziedzinie praw człowieka - przykłady działań Unii Europejskiej na arenie międzynarodowej}

UE dąży do osiągnięcia celów w zakresie praw człowieka i demokracji, określając ogólne zasady, na których opiera się jej polityka w tej dziedzinie. Zasady te mogą znaleźć odzwierciedlenie we wspólnych strategiach, w przypadku gdy UE i państwa członkowskie mają istotne wspólne interesy (np. Rosja, rejon śródziemnomorski), „wspólnych działaniach”, gdy podjęcie działań operacyjnych przez UE zostanie uznane za niezbędne (np. mianowanie specjalnych przedstawicieli UE oraz operacje zarządzania kryzysowego) lub we „wspólnych stanowiskach”, w sytuacji gdy chodzi o wyrażenie stanowiska UE w konkretnej kwestii merytorycznej lub geograficznej. W ciągu kilku ostatnich lat UE prowadziła dialog dotyczący praw człowieka z takimi państwami, jak Chiny czy Iran oraz nałożyła sankcje za pogwałcenie praw człowieka na kilka krajów, np. na Serbię, Birmę (Myanmar) i Zimbabwe. W ramach działań na rzecz praw człowieka UE wysyła swoich obserwatorów na wybory w krajach całego świata oraz organizuje pomoc humanitarną dla ofiar klęsk żywiołowych, wojen i konfliktów zbrojnych ${ }^{35}$. Zgodnie z art. 214 TfUE pomoc humanitarna świadczona przez UE ma na celu „,niesienie doraźnej pomocy i opieki dla ludności w państwach trzecich, która stała się ofiarą klęsk żywiołowych lub katastrof spowodowanych przez człowieka, oraz jej ochronę, w celu sprostania potrzebom humanitarnym wynikającym z takich różnych sytuacji. Działania Unii i Państw Członkowskich wzajemnie się uzupełniają

\footnotetext{
$35 \mathrm{Na}$ temat pomocy humanitarnej udzielanej przez UE zob.: A. Zygierewicz, Pomoc humanitarna Unii Europejskiej, http://orka.sejm.gov.pl/WydBAS.nsf/0/082B87A75A7C16D3C12575E60027ABD2/\$file/Infos_ 59.pdf, dostęp: 30.7.2017; Pomoc humanitarna i ochrona ludności, https://publications.europa.eu/pl/publicationdetail/-/publication/02e57613-b5d2-11e5-8d3c-01aa75ed71a1, dostęp: 30.7.2017.
} 
i wzmacniają"36. Zatem działania UE w obszarze pomocy humanitarnej mają na celu zapewnienie ochrony podstawowych praw człowieka ${ }^{37}$.

Unia działa na terenach głównych konfliktów, w tym w Syrii, na Ukrainie, na obszarach dotkniętych ebolą w Afryce Zachodniej, a także w Republice Środkowoafrykańskiej oraz w państwach niestabilnych w wyniku konfliktu, takich jak Wybrzeże Kości Słoniowej. Od 1992 r. udziela pomocy humanitarnej w ponad 140 państwach dla ok. 120 mln osób rocznie, przy czym roczny budżet na operacje humanitarne wynosi maksymalnie 1 mld euro ${ }^{38}$. $\mathrm{Na}$ uwagę zasługuje współpraca UE z ONZ w dziedzinie praw człowieka. 4.5.2011 r. UE uzyskała status ,superobserwatora” w Zgromadzeniu Ogólnym ONZ ${ }^{39}$, dzięki czemu przewodniczący Rady Europejskiej i wysoki przedstawiciel Unii do spraw zagranicznych i polityki bezpieczeństwa mają prawo zabierania głosu, odpowiedzi, a także zgłaszania propozycji i poprawek $\mathrm{w}$ imieniu państw członkowskich UE. W dziedzinie pomocy humanitarnej UE realizuje współpracę z ONZ poprzez Departament Pomocy Humanitarnej (ECHO) działający w ramach Komisji Europejskiej.

Sposób pojmowania praw podstawowych przez Unię oraz zakres ich stosowania $\mathrm{W}$ stosunkach zewnętrznych obrazują wydarzenia związane $\mathrm{z}$ interwencją humanitarną w Kosowie w 1999 r. oraz z tzw. ,ppomarańczową rewolucją na Ukrainie w 2004 r., jak również relacje z Turcją, w szczególności rokowania z $2007 \mathrm{r} .{ }^{40}$. we wszystkich tych przypadkach Unia, $\mathrm{w}$ imię ochrony praw podstawowych, podejmowała określone działania wobec suwerennego państwa, reagując na wydarzenia dotyczące jego sytuacji wewnętrznej.

Z powyższego wynika, że promocja praw człowieka w stosunkach zewnętrznych UE odbywa się przede wszystkim za pomocą instrumentów o charakterze ekonomicznohandlowym. Ponadto, zasadniczym problemem, na który wskazuje doktryna, jest nierówne traktowanie w UE kwestii praw podstawowych w stosunkach pro foro interno i pro foro externo $^{41}$. Wskazuje się na łamanie praw człowieka w państwach będących największymi

\footnotetext{
${ }^{36}$ Artykuł 214 TfUE.

$37 \mathrm{~W}$ doktrynie funkcjonuje również koncepcja prawa do pomocy humanitarnej jako powszechnego prawa człowieka. Zob. M. Balcerzak, Pomoc humanitarna a międzynarodowa ochrona praw człowieka [w:] Pomoc humanitarna w świetle prawa i praktyki, red. P. Grzebyk, E. Mikos-Skuza, Warszawa 2016, s. 28-32.

${ }^{38} \mathrm{https}$ ://europa.eu/european-union/topics/humanitarian-aid-civil-protection_pl, dostęp: 29.7.2017.

${ }^{39}$ Do niedawna UE miała w ONZ status obserwatora i reprezentowana była przez kraje rotacyjnej prezydencji. 3.5.2011 r. Zgromadzenie Ogólne ONZ przyjęło rezolucję 65/276, na podstawie tórej UE otrzymała prawie wszystkie prawa przysługujące państwom: prawo wypowiedzi, składania propozycji i wniosków o dokonywanie zmian, udzielania odpowiedzi, wnoszenia kwestii porządkowych i dystrybucji dokumentów".

${ }^{40}$ Zob. P. Turczyński, Prawa podstawowe $w$ polityce zagranicznej Unii Europejskiej [w:] Ochrona praw podstawowych $w$ Unii Europejskiej..., op.cit., s. 89-97.

${ }^{41}$ K. Marciniak, op.cit., s. 586 i n.; J.H.H. Weiler, An 'Ever Closer Union' in Need of a Human Rights Policy: The European Union and Human Rights [w:] The EU and Human Rights, P. Alston (red.), „Oxford University Press” 1999, s. 3-7; P. Turczyński, op.cit., s. 81.
} 
partnerami gospodarczymi UE, które dzięki swojej pozycji międzynarodowej, pomimo nieprzestrzegania prawa międzynarodowego, w wielu sytuacjach pozostają praktycznie bezkarne. Dlatego też Unia była wielokrotnie „oskarżana” o relatywizm etyczny ${ }^{42}$, niekonsekwencję i stosowanie podwójnych standardów, przekładanie interesów gospodarczych nad wartości zapisane $\mathrm{w}$ traktach $\mathrm{i}$ deklarowane $\mathrm{w}$ aktach prawa pochodnego ${ }^{43}$. Kwestia ta ma istotne znaczenie z punktu widzenia spójności działań Unii, ale z uwagi na swój zakres wykracza poza przedmiot niniejszego opracowania,

\section{Podsumowanie}

Z przeprowadzonej analizy wynika, że prawa człowieka są istotnym aspektem polityki zagranicznej Unii Europejskiej, ponieważ organizacja ta promuje poszanowanie praw człowieka nie tylko w państwach członkowskich, ale również w swoich działaniach zewnętrznych - stosunkach $\mathrm{z}$ państwami trzecimi i organizacjami międzynarodowymi. Do głównych instrumentów realizacji celów UE w dziedzinie praw człowieka należy zaliczyć: przyjmowanie wytycznych polityki UE w zakresie kluczowych problemów dotyczących praw człowieka, włączanie problematyki praw człowieka i demokratyzacji do wszystkich aspektów związanych z podejmowaniem przez Unię decyzji politycznych i ich wdrażaniem, w tym do pomocy zewnętrznej, włączanie klauzuli dotyczącej praw człowieka i demokracji do umów zewnętrznych zawieranych przez UE oraz Europejski instrument na rzecz demokracji i praw człowieka.

Reasumując, należy zauważyć, że choć UE w stosunkach zewnętrznych bardzo akcentuje kwestie dotyczące praw człowieka, zdarza się, że w praktyce stosuje odmienne standardy. Stawia to pod znakiem zapytania możliwość wypracowania naprawdę spójnej polityki unijnej w omawianej dziedzinie.

\footnotetext{
${ }^{42}$ G. Michałowska, Ochrona praw czlowieka w Radzie Europy $i$ w Unii Europejskiej, Warszawa 2007, s. 270 i n.

${ }^{43}$ Zob. np. O. Gorm, Promotion of democracy as a foreign policy instrument of 'Europe': Limits to international idealism, „Democratization” 2000, nr 7, s. 142 i n.
} 


\begin{abstract}
Summary
Human rights in the European Union's foreign policy - legal framework

The article describes legal issues related to human rights in EU foreign policy. The European Union ('EU') promotes respect for human rights not only in the Member States but also in its external relations - relations with third countries and international organizations. According to Art. 21 the treaty on EU, the EU international actions are based on the principles of democracy, the rule of law, the universality and indivisibility of human rights and fundamental freedoms, respect for human dignity, the principles of equality and solidarity and respect for the principles of the United Nations Charter and international law. The main instruments for achieving the EU's goals in the field of human rights are following: the adoption of EU policy guidelines on key human rights issues, the integration of human rights and democratization into all aspects of EU decision-making, including external assistance and also use the human rights and democracy clause in EU external agreements and the European Instrument for Democracy and Human Rights.
\end{abstract}

\title{
Iwona Miedzińska
}

Prawnik, politolog, doktorantka w Instytucie Prawa Międzynarodowego na Wydziale Prawa i Administracji Uniwersytetu Warszawskiego; starszy specjalista w Departamencie Obsługi Prawnej w Urzędzie Transportu Kolejowego. Uczestniczka krajowych i międzynarodowych konferencji naukowych, autorka kilkunastu artykułów poświęconych prawu unijnemu i systemowi instytucjonalnemu Unii Europejskiej. Zainteresowania badawcze: prawo i system instytucjonalny Unii Europejskiej, integracja europejska, polityka zagraniczna i stosunki zewnętrzne Unii Europejskiej, polityka i prawo Unii Europejskiej w sektorze transportu kolejowego; prawa człowieka i systemy ich ochrony. 